\title{
HUBUNGAN PENGETAHUAN, SIKAP, DAN PERATURAN DENGAN TINDAKAN KESEHATAN LINGKUNGAN SEKOLAH PADA SISWA KELAS VIII DI SMPN 24 TANGERANG DAN SMPN 28 TANGERANG
}

\author{
Mega Revy Pratiwi, Nur Asiah, Ikhwan Ridha Wilti \\ Universitas Muhammadiyah Prof. Dr. HAMKA Jurusan Kesehatan Masyarakat \\ Jl. Limau II, RT.3/RW.3, Kramat Pela, Kec. Kby. Baru, Kota Jakarta Selatan, \\ Daerah Khusus Ibukota Jakarta 12130 \\ e-mail: megarevy@gmail.com
}

\begin{abstract}
Correlation Between Knowledge, Attitude, and School Regulations with School Environmental Health Measures for VIII Class Students. The health of the school environment is an effort that aims to improve, realize and develop the optimal degree of student health. However, there are still many students who do not really care about environmental problems so that they have not been realized in real action. SMPN 24 Tangerang and SMPN 28 Tangerang. This study used a cross sectional. The purpose of this study was to determine the relationship between knowledge, attitudes, and regulations with the actions of the VIII graders at approach. The population was all students of class VIII at SMPN 24 Tangerang and SMPN 28 Tangerang with a total sample of 245 students. The data source used is primary data with data collection methods in the form of interviews with a questionnaire instrument. The results showed that, there is a relationship between attitudes and actions regarding the health of the school environment in class VIII students at SMPN 24 Tangerang (Pvalue 0.027) and SMPN 28 Tangerang (Pvalue 0.011) in 2020. It is hoped that the school can continue to motivate and educate students about environmental health through posters, counseling, or other environmental programs.
\end{abstract}

Keywords: School Environmental Health; Junior High School; School Regulation; Knowledge; Attitudes; and Actions

\begin{abstract}
Abstrak: Hubungan Pengetahuan, Sikap, dan Peraturan Dengan Tindakan Kesehatan Lingkungan Sekolah Pada Siswa Kelas VIII. Kesehatan lingkungan sekolah merupakan upaya yang bertujuan untuk meningkatkan, mewujudkan dan mengembangkan derajat kesehatan siswa secara optimal. Namun, masih banyak diantara siswa yang belum peduli dengan permasalahan lingkungan secara sungguh-sungguh sehingga belum terwujud dalam tindakan nyata. Tujuan penelitian ini untuk mengetahui hubungan antara pengetahuan,sikap,dan peraturan dengan tindakan siswa kelas VIII di SMPN 24 Tangerang dan SMPN 28 Tangerang.Penelitian ini menggunakan pendekatan cross sectional. Populasi adalah semua siswa kelas VIII di SMPN 24 Tangerang dan SMPN 28 Tangerang dengan jumlah sampel sebanyak 245 siswa. Sumber data yang digunakan adalah data primer dengan metode pengumpulan data berupa wawancara dengan instrumen kuesioner. Hasil penelitian didapatkan bahwa terdapat hubungan antara sikap dengan tindakan mengenai kesehatan lingkungan sekolah pada siswa kelas VIII di SMPN 24 Tangerang(Pvalue 0,027) dan SMPN 28 Tangerang (Pvalue 0,011) tahun 2020. Diharapkan kepada pihak sekolah dapat terus memotivasi dan mengedukasi para siswa mengenai kesehatan lingkungan baik itu melalui poster, penyuluhan, ataupun programprogram lingkungan yang lainnya.
\end{abstract}

Kata Kunci: Kesehatan Lingkungan Sekolah; Sekolah Menengah Pertama; Sekolah Adiwiyata; Pengetahuan; Sikap; Peraturan dan Tindakan

\section{PENDAHULUAN}

Salah satu upaya yang bertujuan untuk mewujudkan serta meningkatkan derajat kesehatan siswa yaitu melalui kesehatan lingkungan sekolah. Menjaga kesehatan lingkungan sekolah bukan 
hanya pada murid, guru dan staf sekolah lainya, tetapi sampai masyarakat di luar lingkungan sekolah. Karena sekolah merupakan tempat perkumpulan para siswa pada aktivitas belajar mengajar. Oleh karena itu, lingkungan sekolah yang aman, sehat serta nyaman sangat diperlukan dalam proses belajar mengajar.

Kondisi lingkungan sekolah yang tidak memadai dapat menjadi faktor risiko timbulnya berbagai macam gangguan kesehatan baik itu berupa kecelakaan maupun penyebaran penyakit berbasis lingkungan yang menular. Berbagai penyakit berbasis lingkungan diantaranya yaitu diare, DBD, ISPA, dan lain sebagainya (Purba, 2010 dalam Posmaningsih, 2014). Pada tahun 2006 Kementerian Lingkungan Hidup (KLH) melakukan pengembangan pada jenjang pendidikan dasar maupun menengah yaitu program pendidikan tentang lingkungan hidup yaitu dengan diadakannya program Adiwiyata, yaitu suatu program yang dicanangkan oleh Kementerian Negara Lingkungan Hidup yang bertujuan sebagai upaya pelestarian lingkungan dengan cara membentuk karakter yang peduli terhadap lingkungan, baik itu pengetahuan dan kesadaran warga sekolah. Untuk mewujudkan sekolah yang berwawasan lingkungan, maka sekolah harus dapat menerapkan berbagai komponen yang termasuk kedalam program Adiwiyata.

Menurut data Bidang Penataan dan Peningkatan Kapasitas Lingkungan Hidup pada Dinas Lingkungan Hidup (DLH) Kota Tangerang sampai tahun 2017 jumlah sekolah Adiwiyata berdasarkan jenjang pendidikan SD, SMP, SMA sederajat di Kota Tangerang sebanyak 24 sekolah. Berdasarkan Kepmenkes Nomor 1429 tahun 2006 mengenai pedoman penyelenggaraan kesehatan lingkungan sekolah, bahwa seluruh sekolah harus menerapkan pedoman tersebut yang bertujuan untuk meningkatkan kualitas dari kesehatan lingkungan serta perilaku hidup bersih dan sehat pada sekolah, sehingga dapat terwujudnya sekolah yang memiliki lingkungan bersih, sehat nyaman dan terhindar dari berbagai hal yang menyebabkan penyakit.

SMP Negeri 24 Tangerang adalah Sekolah Menengah Pertama (SMP) yang telah berpredikat Adiwiyata Mandiri. Sebagai sekolah yang mendapat predikat Adiwiyata Mandiri. SMP Negeri 28 Tangerang merupakan sekolah menengah pertama negeri yang terhitung masih baru. Sekolah ini merupakan sekolah yang baru berdiri tahun 2017 dan belum mendapat predikat sekolah Adiwiyata. Walaupun baru, SMP Negeri 28 Tangerang tidak jauh berbeda dengan SMP Negeri 24Tangerang, karena sudah mulai menerapkan beberapa aspek dari program Adiwiyata seperti adanya program penghijauan sekolah, larangan merokok di area sekolah serta larangan membuang sampah sembarangan.

Walaupun program Adiwiyata yang terapkan pada sekolah-sekolah ini memiliki tujuan untuk menerapkan sekolah yang memiliki kepedulian terhadap lingkungan serta berbudaya lingkungan. Berdasarkan hasil penelitian sebelumnya didapatkan hasil bahwa bagi sekolah yang sudah mendapatkan predikat Adiwiyata belum menjamin untuk memiliki tingkat pemahaman yang baik tentang lingkungan, serta sikap maupun tindakan yang dapat mencerminkan kepeduliannya terhadap lingkungan (Dewi, 2017).

Berdasarkan hasil observasi masih ditemukan sampah berserakan serta kondisi toilet sekolah yang masih berbau serta kotor. Dari hasil wawancara mengenai pengetahuan, sikap, dan tindakan siswa tentang komponen kesehatan lingkungan sekolah kepada 15 orang siswa hanya 9 siswa yang memiliki pengetahuan dan sikap mengenai pelaksanaan serta manfaat kesehatan lingkungan, serta hanya mengetahui teori tapi tidak dilaksanakan. Didapatkan bahwa 6 siswa mengaku masih membuang sampah sembarangan, terutama ketika sudah diluar lingkungan sekolah, serta belum mengetahui dampak positif dan negatif atas tindakannya, dan belum tahu manfaat dari tindakan berwawasan lingkungan. Karena siswa 
mengaku hanya mengikuti perintah pihak sekolah atau ikut-ikutan tanpa mengetahui manfaat dari kegiatan yang dilakukan sehingga siswa belum peduli dengan permasalahan lingkungan.

Berdasarkan hal tersebut penulis ingin mengetahui Hubungan Pengetahuan, Sikap, dan Peraturan Sekolah dengan Tindakan Menganai Kesehatan Lingkungan Sekolah pada Siswa Kelas VIII di SMPN 24 Tangerang dan SMPN 28 Tangerang Tahun 2020.

\section{BAHAN DAN CARA PENELITIAN}

Penelitian ini merupakan jenis penelitian analitik menggunakan pendekatan cross sectional. Penelitian ini bertujuan untuk mengetahui hubungan pengetahuan, sikap, dan peraturan sekolah dengan tindakan kesehatan lingkungan sekolah pada siswa kelas VIII di SMPN 24 Tangerang dan SMPN 28 Tangerang tahun 2020 .

\section{HASIL PENELITIAN DAN PEMBAHASAN}

Tabel 1. Perbandingan Pengetahuan, Sikap, Peraturan dan Tindakan mengenai Kesehatan Lingkungan Sekolah di SMPN 24 Tangerang dan SMPN 28 Tangerang Tahun 2020

\begin{tabular}{lccccc}
\hline & & \multicolumn{2}{c}{ SMPN24Tangerang } & \multicolumn{2}{c}{ SMPN 28 Tangerang } \\
\hline Pengetahuan & & Jumlah & $\%$ & Jumlah & $\%$ \\
- Tinggi & & 92 & 67,6 & 64 & 58,7 \\
- Rendah & & 44 & 32,4 & 45 & 41,3 \\
& Total & 136 & 100,0 & 109 & 100,0 \\
Sikap & & & & & \\
- Positif & & 73 & 53,7 & 58 & 53,2 \\
- Negatif & & 63 & 46,3 & 51 & 46,8 \\
& Total & 136 & 100,0 & 109 & 100,0 \\
Tindakan & & & & & \\
- Baik & & 66 & 48,5 & 26 & 23,9 \\
- Kurang Baik & 70 & 51,5 & 83 & 76,1 \\
& Total & 136 & 100,0 & 109 & 100,0 \\
Peraturan & & & & & \\
- Ya & & 112 & 82,4 & 77 & 70,6 \\
- Tidak & & 24 & 17,6 & 32 & 29,4 \\
\multicolumn{2}{l}{ Total } & 136 & 100,0 & 109 & 100,0 \\
\hline
\end{tabular}

Berdasarkan Tabel 2 secara keseluruhan tingkat pegetahuan, sikap, tindakan, serta peraturan/sanksi yang berkaitan dengan kesehatan lingkungan sekolah di SMPN 24 Tangerang dan SMPN
Populasi dalam penelitian ini adalah seluruh siswa di Sekolah Menengah Pertama Negeri yaitu siswa SMP kelas VIII di SMPN 24 yang berjumlah 350 siswa dan SMPN 28 yang berjumlah 282 siswa, sehingga jumlah populasi dari kedua sekolah adalah 632 siswa.

Teknik pengambilan sampel menggunakan rumus dari Slovin dalam Riduwan (2012). Jumlah sampel dari masing-masing sekolah adalah 136 siswa pada SMPN 24 dan 109 siswa pada SMPN 28. Pengambilan sampel diambil secara proportional random sampling. Variabel Independen adalah pengetahuan sikap dan peraturan kesehatan lingkungan sekolah sedangkan variabel dependen tindakan mengenai kesehatan lingkungan sekolah. Pengambilan data menggunakan kuesioner terstruktur serta lembar observasi lingkungan sekolah. Dalam analisis data menggunakan uji Chi Square, dengan bantuan program SPSS.

28 Tangerang didapatkan hasil bahwa tingkat pengetahuan siswa di kedua sekolah lebih banyak yg termasuk dalam kategori tinggi, dimana SMPN 24 memiliki 
pengetahuan 8,9 \% lebih tinggi dari SMPN 28.

Untuk sikap di kedua sekolah tersebut lebih banyak yang termasuk dalam kategori positif, dimana SMPN 24 memiliki sikap positif $0,5 \%$ lebih tinggi dari SMPN 28, Untuk tindakan dikedua sekolah tersebut termasuk dalam kategori kurang baik, dimana SMPN 28 memiliki tindakan kurang baik 27,6\% lebih tinggi dari SMPN 24. Untuk variabel peraturan dikedua sekolah tersebut perbedaannya yaitu 11,8\%, dimana persentase siswa yang mengetahui adanya peraturan lebih tinggi berada di SMPN $24(82,4)$

Tabel 2. Rekapitulasi Uji Chi Square Antara Variabel Independen dengan Tindakan Mengenai Kesehatan Lingkungan Sekolah Pada Siswa di SMPN 24 Tangerang dan SMPN 28 Tangerang tahun 2020

\begin{tabular}{lc}
\hline \multicolumn{1}{c}{ Variabel } & P-value \\
\hline SMPN 24 Tangerang & \\
Pengetahuan & 0,674 \\
Sikap & 0,027 \\
Peraturan & 0,157 \\
SMPN 28 Tangerang & \\
Pengetahuan & 0,915 \\
Sikap & 0,011 \\
Peraturan & 0,292 \\
\hline
\end{tabular}

Berdasarkan tabel 2 rekapitulasi uji chi square antara variabel independen dengan tindakan mengenai kesehatan lingkungan sekolah pada siswa di SMPN 24 Tangerang dan SMPN 28 Tangerang tahun 2020 bahwa terdapat satu variabel yang berhubungan dengan tindakan mengenai kesehatan lingkungan sekolah dikedua sekolah tersebut yaitu variabel sikap dengan P-value 0,027 pada SMPN 24 Tangerang, dan P-value 0,011 pada SMPN 28 Tangerang.

Pengetahuan tercipta dari hasil tahu, dan hal ini terjadi saat seseorang telah melakukan penginderaan akan suatu objek tertentu. Terjadinya penginderaan melalui pancaindera yang dimiliki manusia, diantaranya yaitu indera penglihatan, pendengaran, penciuman, rasa, dan raba (Notoatmodjo, 2012).

Berdasarkan hasil penelitian menunjukkan bahwa tingkat pengetahuan siswa sekolah menengah pertama kelas VIII mengenai kesehatan lingkungan sekolah di Sekolah yang sudah berpredikat Adiwiyata yaitu SMPN 24 Tangerang mempunyai tingkat pengetahuan tinggi yaitu sebesar 67,6\%.

Sekolah yang berpredikat Adiwiyata yaitu SMPN 24 Tangerang didapat- kan hasil bahwa siswa paling banyak menjawab benar pada pertanyaan mengenai syarat tempat sampah yang baik, mengapa tidak boleh merokok, dan mengapa harus menjaga kesehatan lingkungan sekolah. Siswa paling banyak menjawab salah pada item pertanyaan mengenai pengertian sampah.

Hasil bivariat hubungan antara pengetahuan dengan tindakan mengenai kesehatan lingkungan sekolah di SMPN 24 didapatkan $\mathrm{p}$-value sebesar 0,674 dari kemaknaan $\alpha=0,05$. Hal ini memiliki arti bahwa tidak terdapat hubungan antara pengetahuan dengan tindakan mengenai kesehatan lingkungan sekolah di SMPN 24 Tangerang..

Dari hasil penelitian pengetahuan tinggi siswa disekolah Adiwiyata ini dipengaruhi oleh prinsip sekolah adiwiyata itu sendiri yaitu mengintegrasikan pengetahuan mengenai lingkungan ke dalam mata pelajaran wajib dan penggunaan metode belajar tenaga pendidik yang melibatkan siswa turut aktif. Menurut peneliti, hal ini juga dipengaruhi oleh faktor lain yaitu tersedianya berbagai media informasi disekolah seperti tersedianya berbagai poster mengenai lingkungan. Karena 
pengetahuan seseorang dipengaruhi oleh beberapa faktor, diantaranya; pendidikan, media dan keterpaparan informasi (Darmawan, 2016).

Hal ini sejalan dengan penelitian yang dilakukan oleh Bawole yang berjudul "Hubungan Antara Tingkat Pengetahuan Dan Sikap Dengan Tindakan Perilaku Hidup Bersih dan Sehat Pada Murid Sekolah Dasar Gmim 9 dan Sekolah Dasar Negeri Inpres Pinangunian Kota Bitung" yang hasilnya adalah tidak ada hubungan pengetahuan dengan tindakan perilaku hidup bersih dan sehat pada murid sekolah dasar GMIM 9 dan Negeri Inpres Pinangunian Kota Bitung (P-value 0,213). Berdasarkan hasil penelitian menunjukkan bahwa tingkat pengetahuan siswa sekolah menengah pertama kelas VIII mengenai kesehatan lingkungan sekolah di sekolah yang belum berpredikat Adiwiyata yaitu SMPN 28 Tangerang mempunyai tingkat pengetahuan tinggi. Pada siswa di SMPN 28 Tangerang sebesar $58,7 \%$.

Disisi lain, SMPN 28 Tangerang memiliki persentase pengetahuan yang lebih rendah dibanding SMPN 24 namun masih termasuk dalam kategori tinggi.

Hasil bivariat hubungan antara pengetahuan dengan tindakan mengenai kesehatan lingkungan sekolah di SMPN 28 didapatkan p-value sebesar 0,915 dari kemaknaan $\alpha=0,05$. Hal ini memiliki arti bahwa tidak terdapat hubungan antara pengetahuan dengan tindakan mengenai kesehatan lingkungan sekolah di SMPN 28.

Hal ini sejalan dengan penelitian yang dilakukan oleh Martini yang berjudul "Hubungan Antara Pengetahuan Lingkungan Dengan Perilaku Prolingkungan Sekolah Adiwiyata di Kabupaten Agam" yang hasilnya adalah tidak terdapat hubungan antara pengetahuan dengan perilaku prolingkungan di Kabupaten Agam (P-value 0.611).

Faktor lain yang diukur yaitu sikap. Hasil nilai sikap yang diukur dikedua sekolah tersebut memiliki hasil yang sedikit berbeda. Pada SMPN 24 sebanyak 53,7\%. Sikap siswa di SMPN 24 Tangerang termasuk dalam kategori positif karena memang didukung oleh pendidikan mengenai lingkungan hidup yang ada di sekolah tersebut serta faktorfaktor lain pembentuk sikap yang didukung dari adanya penerapan program Adiwiyata. Hasil penelitian variabel sikap di sekolah ini menurut peneliti dipengaruhi juga oleh kondisi lingkungan sekolah yang juga menerapkan unsurunsur keagamaan sehingga siswa cenderung dibentuk persepsinya sesuai dengan nilai-nilai agama atau spiritual.

Penanaman nilai-nilai spiritual memiliki fungsi untuk memberikan dorongan kepada individu untuk melakukan aktivitas yang semata-mata bertujuan untuk melaksanakan perintah Tuhan, selain itu nilai spritual ini juga penting untuk mewujudkan individu yang mempunyai tanggung jawab moral dan sosial di masyarakat (Iswari, 2017).

Hasil bivariat hubungan antara sikap dengan tindakan mengenai kesehatan lingkungan sekolah di SMPN 24 didapatkan p-value sebesar 0,027 dari kemaknaan $\alpha=0,05$. Hal ini memiliki arti bahwa ada hubungan antara sikap dengan tindakan mengenai kesehatan lingkungan sekolah di SMPN 24.

Berdasarkan hasil bivariat disekolah tersebut sejalan dengan penelitian yang dilakukan oleh Tanjung yang berjudul "Hubungan Pengetahuan dan Sikap Siswa Tentang Perilaku Hidup Bersih dan Sehat dengan Tindakan PHBS di SD Swasta Luther Kecamatan Siatas Barita Tapanuli Utara Tahun 2013" di dapatkan hasil bahwa ada hubungan antara sikap dengan Tindakan PHBS di SD Swasta Luther Kecamatan Siatas Barita Tapanuli Utara Tahun 2013 (P-value 0,000 ).

Hasil nilai sikap yang Pada SMPN 28 sebanyak 53,2\% siswa sudah mempunyai sikap yang positif juga. Penanaman nilai-nilai spiritual memiliki fungsi untuk memberikan dorongan kepada individu untuk melakukan aktivitas yang semata-mata bertujuan untuk melaksanakan perintah Tuhan, selain itu nilai spritual ini juga penting untuk mewujudkan individu yang mempunyai 
tanggung jawab moral dan sosial di masyarakat (Iswari, 2017).

Hasil penelitian variabel sikap di sekolah ini menurut peneliti dipengaruhi juga oleh kondisi lingkungan sekolah yang juga menerapkan unsur-unsur keagamaan sehingga siswa cenderung dibentuk persepsinya sesuai dengan nilainilai agama atau spiritual. Serta karena sekolah ini sudah mulai mengupayakan sekolah yang berwawasan lingkungan melalui beberapa program lingkungan seperti penerapan kantin sehat, toilet sehat, dan sebagainya.

Hasil bivariat hubungan antara sikap dengan tindakan mengenai kesehatan lingkungan sekolah di SMPN 28 didapatkan p-value sebesar 0,011 dari kemaknaan $\alpha=$ 0,05 . Hal ini memiliki arti bahwa ada hubungan antara sikap dengan tindakan mengenai kesehatan lingkungan sekolah di SMPN 28. Berdasarkan hasil bivariat disekolah tersebut sejalan dengan penelitian yang dilakukan oleh Bawole yang berjudul "Hubungan Antara Tingkat Pengetahuan dan Sikap Dengan Tindakan Perilaku Hidup Bersih dan Sehat Pada Murid Sekolah Dasar Gmim 9 Dan Sekolah Dasar Negeri Inpres Pinangunian Kota Bitung tahun 2018" di dapatkan ada hubungan antara sikap dengan tindakan terhadap perilaku hidup bersih dan sehat pada murid Sekolah Dasar Gmim 9 dan Sekolah Dasar Negeri Inpres Pinangunian Kota Bitung tahun 2018 (P-value 0,021).

Dalam interaksi sosialnya, individu dapat membentuk pola sikap tertentu terhadap berbagai macam objek yang mereka hadapi. Sehingga ada beberapa faktor yang bisa mempengaruhi dalam pembentukan sikap setiap individu yaitu; Pengalaman pribadi, Kebudayaan, Orang lain yang dianggap penting, Media massa, Institusi atau lembaga pendidikan dan lembaga agama dan Faktor emosi dalam diri individu itu sendiri (Darmawan, 2016).

Hasil penelitian di sekolah tersebut didapatkan bahwa sebagian besar siswa pada kedua sekolah tersebut mengetahui adanya peraturan mengenai kesehatan lingkungan sekolah. Pada SMPN 24 sebesar $82,4 \%$ siswa menyadari adanya tata tertib/peraturan sekolah, dan sebesar
$17,6 \%$ siswa tidak menyadari adanya tata tertib/peraturan sekolah. Di sekolah ini terdapat peraturan/ tata tertib tertulis salah satunya tentang menjaga kesehatan lingkungan yaitu untukl mewujudkan sekolah yang bersih serta sehat. Salah satu tujuannya yaitu menjaga dan memelihara kebersihan kelas masing-masing seperti : tidak membawa makanan kedalam ruang kelas, membuang sampah pada tempat yang telah disediakan. Dimana kewajiban siswa terkait lingkungan yaitu menciptakan dan membiasakan siswa dalam menjaga ketertiban, keindahan, lingkungan sekolah yang selalu asri, bersih , indah dan rapi. Bagi siswa yang tidak mengikuti tata tertib sekolah akan di kenakan sanksi berupa teguran, peringatan tertulis, Skorsing, atau dikembalikan kepada orang tua.

Hasil bivariat hubungan antara peraturan dengan tindakan mengenai kesehatan lingkungan sekolah di SMPN 24 didapatkan p-value sebesar 0,157 dari kemaknaan $\alpha=0,05$. Hal ini memiliki arti bahwa tidak terdapat hubungan antara peraturan/sanksi dengan tindakan mengenai kesehatan lingkungan sekolah di SMPN 24. Menurut Hurlock dalam Maolinda, dkk (2012) bahwa peraturan memiliki tujuan untuk membekali anak melalu pedoman dalam berperilaku yang disetujui dalam situasi tertentu. Peraturan di sekolah membantu terbentuknya perilaku positif para siswa yang menjadi bekal saat mereka terjun ke masyarakat (Raivi, 2015).

Hal ini sejalan dengan penelitian yang dilakukan oleh Hidayat (2011) tentang "Faktor-Faktor Yang Berhubungan Dengan Kebersihan Diri dan Kesehatan Lingkungan Di Pesantren Nurul Huda Desa Cibatu Kecamatan Cisaat Kabupaten Sukabumi Tahun 2011." Hasilnya adalah tidak ada hubungan antara sanksi/peraturan dengan Kebersihan Diri Dan Kesehatan Lingkungan di Pesantren Nurul Huda Desa Cibatu (P-value 1,000).

Pada SMPN 28 Tangerang sebesar $70,6 \%$ siswa menyadari adanya peraturan/tata tertib di sekolahnya dan sebesar 29,4\% tidak menyadari adanya peraturan/tata tertib disekolahnya. 
Sekolah ini merupakan sekolah yang sedang mengupayakan terwujudnya sekolah Adiwiyata atau sekolah yang berwawasan lingkungan. Di sekolah ini terdapat peraturan/ tata tertib tertulis salah satunya tentang menjaga kesehatan lingkungan yaitu seluruh siswa wajib berperan serta dalam mewujudkan Sekolah Sehat. Tata tertib ini senantiasa di sosialisasikan kepada siswa salah satunya melalui janji siswa yang senantiasa di lafalkan saat upacara berlangsung. Hal ini dilakukan demi terwujudnya salah satu tujuan sekolah SMPN 28 Tangerang yaitu Terciptanya lingkungan sekolah yang Clean \& Green, indah, sehat dengan cara melestarikan lingkungan sekitar sekolah.

Adanya peraturan sekolah diharapkan siswa SMPN 28 Tangerang mampu membatasi dirinya untuk tidak bertindak semena-mena yang berkaitan dengan lingkungan dimanapun berada. Peraturan tidak memberatkan akan tetapi membentuk siswa menjadi orang yang bertanggung jawab. Apabila siswa melaksankan tindakan, perbuatan atau sikap yang bertentangan dengan janji siswa ataupun tata tertib maka siswa harus menanggung segala konsekuensinya, salah satunya dengan membuat penyataan tertulis mengenai pelanggaran yang dilakukan, semua jajaran sekolah berhak mencatat setiap pelanggara oleh siswa bersangkutan pada lembar evaluasi siswa, serta memanggil siswa yang ditemukan melanggar aturan yang tercantum dalam Buku Saku Tata Tertib Siswa. Menunjukkan aturan yang telah dilanggar sekalian memberikan teguran, arahan, pembinaan seperlunya.

Hasil bivariat hubungan antara peraturan dengan tindakan mengenai kesehatan lingkungan sekolah di SMPN 28 didapatkan $p$-value sebesar 0,292 dari kemaknaan $\alpha=0,05$. Hal ini memiliki arti bahwa tidak terdapat hubungan antara peraturan/sanksi dengan tindakan mengenai kesehatan lingkungan sekolah di SMPN 28.

Hal ini sejalan dengan penelitian yang dilakukan oleh Hidayat (2011) tentang "Faktor-Faktor Yang Berhubungan Dengan Kebersihan Diri dan Kesehatan
Lingkungan Di Pesantren Nurul Huda Desa Cibatu Kecamatan Cisaat Kabupaten Sukabumi Tahun 2011." Hasilnya adalah tidak ada hubungan antara sanksi/peraturan dengan Kebersihan Diri Dan Kesehatan Lingkungan di Pesantren Nurul Huda Desa Cibatu (P-value 1,000). Jadi peraturan sekolah bukan merupakan faktor yang ada hubungannya dengan tindakan kesehatan lingkungan sekolah pada siswa kelas VIII di SMPN 24 Tangerang maupun di SMPN 28 Tangerang.

\section{KESIMPULAN DAN SARAN}

Pengetahuan responden mengenai kesehatan lingkungan sekolah dikedua sekolah tersebut termasuk dalam kategori tinggi yaitu pada SMPN 24 Tangerang sebesar $67,6 \%$ dan pada SMPN 28 Tangerang sebesar 58,7\%. Sikap responden dikedua sekolah tersebut termasuk dalam kategori positif yaitu pada SMPN 24 Tangerang sebesar 53,7\% dan pada SMPN 28 sebesar 53,2\%. Tindakan responden mengenai kesehatan lingkungan sekolah dikedua sekolah tersebut termasuk dalam kategori kurang baik yaitu pada SMPN 24 Tangerang sebesar 51,5\%. Pada SMPN 28 sebesar $76,1 \%$.

Responden dikedua sekolah tersebut banyak yang mengetahui adanya peraturan disekolahnya yaitu pada SMPN 24 Tangerang sebesar $82,4 \%$, pada SMPN 28 Tangerang sebesar $70,6 \%$. Terdapat hubungan antara variabel sikap dengan tindakan siswa kelas VIII mengenai kesehatan lingkungan sekolah di SMPN 24 Tangerang dan di SMPN 28 Tangerang. Berdasarkan kesimpulan tersebut dapat disarankan bagi sekolah yang sudah mendapat predikat Adiwiyata dapat mempertahankan dan meningkatkan prestasi yang sudah dicapai dalam program Adiwiyata. Serta kepada kepala sekolah dan guru-guru yang mengajar dapat senantiasa memberikan informasi tentang kesehatan lingkungan sekolah dan sosialisasi program Adiwiyata kepada para siswa. Bagi sekolah yang belum Adiwiyata, hendaknya kepala sekolah dan guru-guru yang mengajar juga dapat senantiasa memberikan informasi tentang 
sanitasi kesehatan lingkungan sekolah dan sosialisasi program Adiwiyata kepada para siswa dalam bentuk ceramah, diskusi, leaflet maupun brosur. Bagi peneliti lain diharapkan untuk dapat mengembangkan penelitian seperti ini dan dapat mengembangkan variabelvariabel lain yang dapat mempengaruhi tindakan siswa mengenai kesehatan lingkungan.

\section{KEPUSTAKAAN}

1. Akdon, R. (2007). Rumus dan Data dalam Aplikasi Statistika. Bandung: Alfabeta

2. Arifin, M. H., \& Wijayanti, Y. (2019). Higiene dan Sanitasi Makanan di Kantin Sekolah Dasar dan Madrasah Ibtidaiyah, 3(3), 442-453.

3. Ariantika (2017). Pengetahuan, Sikap dan Tindakan Siswa Tentang Kesehatan Lingkungan Sekolah pada Sekolah Menengah Pertama Negeri yang Sudah dan Belum Mendapat Predikat Sekolah Adiwiyata Kecamatan Medan Kota Tahun 2017.

4. Arikunto, S. (2010). Prosedur Penelitian Suatu Pendekatan Praktik. Jakarta: Rineka Cipta.

5. Ayu, D., Posmaningsih., Purna, I. N., \& Notes, N. (2014). Hubungan Stake Holder Sekolah Terhadap Kualitas Kesehatan Lingkungan Sekolah Dasar Di Kecamatan Denpasar Selatan Tahun 2014. Jurnal Skala Husada, 12, 70-78.

6. Cindy E. Z. Hutapea, Adisti A. Rumayar, F. R. R. M. (2017). Hubungan Antara Pengetahuan Dan Sikap Dengan Tindakan Terhadap Kebijakan Kawasan Tanpa Rokok Pada Siswa Di Smp Kristen Tateli. Jurnal Kesehatan Masyarakat Universitas Sam Ratulangi, 1-13.

7. Dasrita, Y., Saam, Z., Amin, B., \& Siregar, Y. I. (2015). Kesadaran Lingkungan Siswa Sekolah Adiwiyata, 2, 61-64.

8. Febriyanti, Y. (2016). Pengaruh Program Adiwiyata Terhadap Pengetahuan Dan Sikap Peduli Lingkungan Hidup Siswa Di Sma
Negeri Kota Medan. Jurnal Pendidikann Biologi.

9. Sari, I. P. T. P. (2013). Pendidikan kesehatan sekolah sebagai proses perubahan perilaku siswa. Jurnal Pendidikan Jasmani Indonesia, 9(2).

10. Wahyuni, N. P. D. S. (2013). Program Dokter Kecil sebagai Upaya Meningkatkan Perilaku Hidup Bersih dan Sehat pada Siswa Sekolah Dasar. In Prosiding Seminar Nasional MIPA.

11. Mukminin, A. (2014). Strategi Pembentukan Karakter Peduli Lingkungan di Sekolah Adiwiyata Mandiri. Ta'dib: Journal of Islamic Education (Jurnal Pendidikan Islam), 19(02), 227-252.

12. Saputra, J. (2016). Studi Deskriptif Sanitasi Kantin Dan Fasilitas Sanitasi Dasar Di Lingkungan Sekolah Dasar Pada Wilayah Kerja Puskesmas Ungaran Kecamatan Ungaran Barat, Kabupaten Semarang Tahun 2016 (Doctoral dissertation, Universitas Negeri Semarang)

13. Tanjung, N. (2016). Hubungan Pengetahuan dan Sikap Siswa Tentang Perilaku Hidup Bersih dan Sehat Dengan Tindakan PHBS Di SD Swasta Luther Kecamatan Siatas Barita Tapanuli Utara Tahun 2013. Jurnal Mutiara Kesehatan Masyarakat, 1(1), 43-52.

14. Kementerian Lingkungan Hidup dan Kementerian Pendidikan dan Kebudayaan. 2014. Panduan Adiwiyata Sekolah Peduli dan Berbudaya Lingkungan.EBook.https://nanopdf.com/downloa d/panduan-adiwiyata-gera-shiagainstitut pdf Diakses pada tanggal 15 Januari 2020, jam 13.24 WIB.

15. Notoatmodjo, S. 2012. Kesehatan Masyarakat Ilmu dan Seni, Jakarta: Rineka Cipta

16. Iswari Dewi, R., \& Utomo, S. W. (2017). Evaluasi Penerapan Program Adiwiyata Untuk Membentuk Perilaku Peduli Lingkungan di Kalangan Siswa. Jurnal Ilmu Lingkungan, 35-41.

17. Kurniadi, D., \& Prapanca, S. (2010). Penjas Orkes kelas IV. Jakarta: Pusat 
Perbukuan Kementerian Pendidikan Nasional.

18. Martini, M. (2019). Hubungan antara Pengetahuan Lingkungan dengan Perilaku Prolingkungan Sekolah Adiwiyata (Studi Kasus Sdn 21 Taluak Kab. Agam). Rang Teknik Journal, 2(1).

19. Notoatmodjo, S. (2010). Promosi Kesehatan Teori dan Aplikasi. Jakarta: PT Rineka Cipta.

20. Notoatmodjo, S. (2011). Kesehatan Masyarakat: Ilmu dan Seni. Jakarta: PT Rineka Cipta.

21. Pranita, E. (2019). Cara Sederhana Bikin Anak Jadi Generasi Sehat, Generasi Unggul.

22. Sumantri, A. (2015). Kesehatan Lingkungan. Jakarta: Kencana Prenada Group.

23. Hendlyana, Y. (2012). Pengelolaan Sanitasi Toilet Umum dan Analisa Kandungan Candida albicans Pada Air Bak Toilet Umum di Beberapa Pasar Tradisional Kota Medan Tahun 2012, 1-8.

24. Hikmah, L., Bm, S., \& Cahyo, K. (2017). Gambaran Kondisi Kantin Sekolah Pada Sekolah Dasar Di Wilayah Kecamatan Tembalang Kota Semarang. Jurnal Kesehatan Masyarakat, 5, 578-586.

25. Murmayani. (2014). Pengaruh Pengetahuan Lingkungan Hidup,
Sikap Lingkungan, dan Motivasi Lingkungan terhadap Perilaku Siswa Memelihara Lingkungan Sekolah di MAN Wajo. Jurnal Kependudukan Dan Lingkungan Hidup, 1-9.

26. Sari, I. P., Ikaningtyas, S., \& Desnaranti, L. (2018). PENINGKATAN MUTU Physical Evidence Di Sekolah Dasar Melalui Gerakan Toilet Ramah Anak. Jurnal Pengabdian Kepada Masyarakat, 01(02), 128-135.

27. Tunggul, E. (2012). Pengelolaan Sumber Air Di Desa Jawesari Kecamata

28. Limbangan, Kabupaten Kendal. Jurnal Kesehatan Masyarakat, 8(1), 17-22.

29. Yulia, A. (2012). Gambaran Faktor Risiko Kesehatan Lingkungan Di Sekolah. http://cheyaliyyaenvironmentepidemiology.blogspot.c om/. diakses pada 2 Januari pukul 13.30 .

30. Zakiudin, A., \& Shaluhiyah, Z. (2016). Perilaku Kebersihan Diri (Personal Hygiene) Santri Di Pondok Pesantren Wilayah Kabupaten Brebes Akan Terwujud Jika Didukung Dengan Ketersediaan Sarana Prasarana. Jurnal Promosi Kesehatan Indonesia, 11(2), 64-83. 
